\title{
FILODEMO DE GÁDARA: SELEÇÃO DE EPIGRAMAS
}

\section{PHILODEMUS OF GADARA: SELECTED EPIGRAMS}

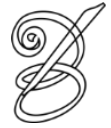 \\ Leonardo Teixeira de OLIVEIRA* \\ Universidade Federal do Paraná \\ Curitiba, Paraná, Brasil
}

Resumo: A poesia do filósofo epicurista Filodemo de Gádara (c. 110 - c. 40 a.C.) é situada na epigramática helenística, com a transformação do epigrama clássico e sua fusão com a elegia por predecessores como Asclepíades de Samos (c. 320 a.C.), Calímaco (310/305 - 240 a.C.) e Meleagro (séc. I a.C.). Escritos em grego, seus epigramas foram elogiados por Cícero (106 - 43 a.C.) e coletados na "Antologia" de Filipe de Tessalônica, no século I d.C., que terminou por ser inclusa na Anthologia Palatina, do século X, assegurando a sua transmissão até a nossa era. Na seguinte seleção, foram traduzidos em versos livres sete breves epigramas do autor, em que se sobressaem a inefabilidade da experiência amorosa, conhecida apenas na subjetividade, e os vários papéis femininos cortejados pela voz poética.

Palavras-chave: Filodemo de Gádara. Poesia lírica grega. Poesia amorosa. Epigrama. Epicurismo.

Abstract: The poetry of the Epicurean philosopher Philodemus of Gadara (c. 110 - c. 40 BC) is situated in the Hellenistic epigramatic poetry, with the transformation of the classic epigram and its fusion with the elegy by predecessors such as Asclepiades of Samos (c. 320 BC), Callimachus (310/305 - 240 BC) and Meleager (1st century BC). Written in Greek, his epigrams were praised by Cicero (106 - 43 BC) and collected in the "Anthology" of Philip of Thessalonica, in the 1st century AD, which ended up being included in the Anthologia Palatina, in the 10th century, ensuring its transmission until our era. In the following selection, seven brief epigrams of the author were translated into free verses, in which the ineffability of the love experience, known only in subjectivity, and the various female roles courted by the poetic voice stand out.

Keywords: Philodemus of Gadara. Greek lyric poetry. Love poetry. Epigram. Epicureanism.

RECEBIDO EM: 18 de setembro 2019

ACEITO EM: 25 de novembro de 2019

PUBLICADO EM: março 2020 
$\mathrm{F}$ lodemo de Gádara (c. 110 - c. 40 a.C.) foi um filósofo epicurista e poeta epigramista nascido na antiga cidade greco-síria de Gádara, ${ }^{1}$ atual Um Qeis, na Jordânia. Tendo estudado na escola epicurista de Atenas sob a supervisão de Zenão de Sídon² (c. 150 c. 75 a.C.), mudou-se para a Itália, ${ }^{3}$ possivelmente em 74-3 a.C., ${ }^{4}$ onde foi patroneado por Lúcio Calpúrnio Pisão Cesonino ${ }^{5}$ (c. 101 - 43 a.C.) (cônsul em 58 a.C.). ${ }^{6}$ Escritos em grego, alguns de seus epigramas foram preservados na Anthologia Palatina ${ }^{7}$ e eram tudo o que se conhecia de sua obra até o século XVIII, quando um conjunto de papiros descoberto nas ruínas da grande vila de Herculano, soterrada pela erupção do Vesúvio em 79 d.C., ${ }^{8}$ deu a conhecer várias de suas obras sobre história da filosofia, ciência, teologia, artes liberais e ética. ${ }^{9}$

Leonardo T. Oliveira (1986-) é mestre em Letras Clássicas pela Universidade de São Paulo, doutorando pela Universidade Federal do Paraná e pesquisa poesia e música grega antigas. Nas traduções a seguir, feitas a partir da edição do texto grego por David Sider (1997), os dísticos elegíacos originais de Filodemo de Gádara são vertidos em versos livres. Nessa poesia, sobressaem-se a inefabilidade da experiência amorosa, conhecida apenas na subjetividade, e os vários papéis femininos cortejados pela voz poética. 
Epigrama 1 Sider (= AP V, 131)

O dedilhar, a fala, os olhos tagarelas, o canto de Xantipa e o fogo que agora se inicia,

ó alma, inflamar-te-ão: o porquê ou quando e como não sei; saberás, infortunada, ao seres esfumaçada.

\section{Epigrama 15 Sider $(=A P V, 25)$}

Toda vez que, ao colo de Cidila, de dia ou de noite, ouso repousar,

sei que corto caminho ao precipício, sei que jogo sempre do alto minha cabeça aos dados.

Mas o que mais me importa? Pois ela é ousada, Eros, toda vez que me arrasta e nem em sonho sabe o princípio do medo.

\section{Epigrama 6 Sider (= AP XI, 34)}

Ter de novo brancas violetas e cantos e de novo vinho quiano e de novo mirra da Síria

e de novo festejar e ter de novo uma puta triscada não quero: odeio tais coisas dadas à loucura.

Coroai-me, porém, com narcisos e dai-me de provar dos aulos cruzados e ungi-me os membros com perfumes de açafrão e embebei-me os pulmões com Baco metimneu e uni-me a uma donzela caseira.

\section{Epigrama 12 Sider $(=A P$ V, 132)}

Ó pé!, ó perna!, ó essas (é certo que morro!) coxas!, ó bunda!, ó púbis!, ó ancas!,

ó ombros!, ó peitos!, ó fino pescoço!, ó mãos, ó (enlouqueço!) olhinhos!,

ó movência ardilosa!, ó beijos mais que tudo deliciosos!, ó (ai de mim!) vozinha!

Se é osca e Flora e não canta Safo, também Perseu amou a indiana Andrômeda.

\section{Epigrama 22 Sider $(=A P \mathrm{~V}, 126)$}

Cinco talentos um deu a outra por um favor, fodeu-a estremecendo-se e, por Deus, nem bela ela é. 
Cinco dracmas eu dei a Lisianassa por doze favores, e fodo uma melhor e às claras.

Das duas, uma: ou eu é que não tenho juízo ou, depois dessa, resta arrancar-lhe as bolas com um machado.

\section{Epigrama 20 Sider $(=A P$ V, 46)}

$H($ omem): Salve! $M$ (ulher): Salve a ti também. H.: Como te chamas?

$$
\text { M.: E tu? H.: Calma, }
$$

apressada! M.: Idem a ti. H.: Não tens alguém?

M.: Sempre: o que me ama. H.: Queres então jantar comigo hoje? M.: Se tu queres... H.: Bem! Por quanto vens?

$M .:$ Nada me adiantes... $-H .:$ Que estranho! $-M .$. ...mas quanto te pareça depois de nos deitarmos, isto me dá. $H .:$ Não és injusta.

Onde estarás? Mandarei buscar. M.: Informa-te. ${ }^{10} H .:$ E a que horas virás? $M .:$ À hora que quiseres. $H .:$ Quero agora. M.: Leva-me.

\section{Epigrama 21 Sider $(=A P$ V, 308)}

Bonita, espera-me: qual é o teu belo nome? Onde é que te encontro? O que quiseres, darei. Nada falas?

Onde moras? Mandarei alguém contigo. Ninguém te tem? Ó arrogante, adeus; nem "adeus" dizes?

Virei a ti de novo e de novo - sei amolecer até mais duras do que tu. Mas por ora adeus, mulher.

\section{REFERÊNCIAS}

MAIURI, Amadeo. Herculaneum and the Villa of the Papyri. Novara: Istituto Geografico de Agostini, 1974.

SIDER, David. The Epigrams of Philodemus. Introduction, Text, and Commentary. Oxford: Oxford University Press, 1997.

\footnotetext{
* Leonardo Teixeira de OLIVEIRA - Bacharel em Letras Clássicas (2012) pela Universidade Federal do Paraná. Mestre em Letras Clássicas (2013-2016) pela Universidade de São Paulo. Doutorando em Letras Clássicas pela Universidade Federal do Paraná. Universidade do Paraná, Setor de Ciências Humanas, Departamento de Polonês, Alemão e Letras Clássicas. Curitiba, Paraná, Brasil.

Currículo acadêmico: http://lattes.cnpq.br/0456923157998295

ORCID: https://orcid.org/0000-0001-5570-0336

E-mail: oliveira.leonardo@gmail.com

${ }^{1}$ Str. 16, 2, 29.
} 
${ }^{2}$ Phld. P.Herc. 1005 col. 14, 4-13. Angeli = Zeno Sid. fr. 11 Angeli-Colaizzo.

${ }^{3}$ Phld. P.Herc. 312, col. 14.

${ }^{4}$ Phld. Rhet. IV, 1, 223, 5 Sudh. Ver Sider (1997: 7-9).

${ }^{5}$ Pai do cônsul homônimo em 15 a.C. Ver Cic. Pis. 68-74. Ver Sider (1997: 5-6 n. 11).

${ }^{6}$ Cic. Pis. 2.

${ }^{7} A P$ 4, 2, 8 e ss. $=$ Phil. 1.

${ }^{8}$ Ver Plin. 65.

${ }^{9}$ Ver Maiuri (1974: 35-9).

${ }^{10}$ Com o verbo $\kappa \alpha \tau \alpha \mu \alpha v \theta \alpha ́ v \omega$, ou ela é elusiva e manda que ele "descubra” onde ela estará, ou a ansiedade dele interrompe a sua resposta, que mal pronunciava um "toma nota..." quando ele pergunta pelo horário. 